\title{
E-quality and e-service equality
}

\author{
Pnina Shachaf \\ Indiana University, Bloomington \\ shachaf@indiana.edu
}

\author{
Shannon M. Oltmann \\ Indiana University, Bloomington \\ soltmann@indiana.edu
}

\begin{abstract}
Research is divided about the potential of e-service to bridge communication gaps, particularly to diverse user groups. According to the existing body of literature, e-service may increase or decrease the quality of service received. This study analyzes the level of service received by different genders and ethnic groups when public librarians answer online reference queries. Quality of e-service was evaluated along three dimensions: responsiveness, reliability, and courtesy. This study found no significant differences among different user groups along any of these dimensions, supporting the argument that the virtual environment facilitates equitable service and may overcome some challenges of diverse user groups.
\end{abstract}

\section{Introduction}

According to the most recent US Census [41], 77\% percent of the population were White; $12 \%$ were Black or African-American; 4\% were Asian; and 14\% of the people in United States were Hispanic (people of Hispanic origin may be of any race). Twelve percent of the people living in United States in 2004 were foreign born and 19\% spoke a language other than English at home. These groups are making growing use of the internet; $73 \%$ of Whites (non-Hispanic), $79 \%$ of (English-speaking) Hispanics, and 60\% of Blacks (non-Hispanics) are using the internet [29]. These diverse user groups make use of online services and in particular online library services.

Service discrimination has been a major social concern in the face-to-face environment and reports on discrimination in public accommodation are not rare. For example, Feagin [14] reported that $79 \%$ of discriminatory actions against African-Americans in public accommodations involved rejection or poor service and LaPiere [23], in the pre- Civil Rights Act era, reported that formal written requests for service were rejected more than in-person requests by minorities.

Research has shown that because computermediated communication decreases social cues and reduces social presence, it may have a democratizing effect on communication resulting in, for example, status equalization [38]. Similarly, claims that the use of email can mediate challenges of cultural diversity and that online heterogeneity improves group performance have been made $[10,11,36]$. Thus, online discrimination may be less common due to the ability of potential targets to eliminate social and group identification cues and to remain anonymous; the relative absence of social cues may mean greater equality of services in the virtual environment [17].

Conversely, there is data to support the fact that the online environment reproduces social and other inequalities (e.g., the digital divide) and enables and supports uninhibited behaviors. Douglas and McGarty [13] claimed that in the virtual environment, people can become less self-aware and less likely to monitor their behavior and therefore more likely to act on impulses that would normally be inhibited. Thus, discrimination is more likely to be expressed overtly due to the anonymous, spontaneous, impersonal, and uninhibited nature of computer-mediated communication [17]. It is likely, therefore, that in the virtual environment subjective bias will be similar to the pre-civil rights era or that greater inequality will arise. While e-services providers will not be likely to deny some resources or services on the basis of group membership, they may find an excuse to behave discriminatorily at the moment [8]. Shachaf [35] reported discriminatory behaviors of librarians against Arabs and African-Americans in academic libraries that provide email responses to reference queries. However, her study was limited in the number of 
transactions, so statistical analysis to determine significance levels could not be conducted. Furthermore, sending requests by unaffiliated user to academic libraries may not be representative of the service level that is provided to the majority of the academic community.

Thus, the current study tries to examine if online discrimination exists in the services that are provided to the general public by librarians. This study assumes that while it is possible that unequal services will increase in the virtual environment, it is also possible that e-service providers may be able to offer unbiased service. This paper is designed to address the following question: Do e-services provide equitable online services to the public? Specifically, the study focuses on race and gender bias in public libraries. Reference questions, which appeared to originate from a specific gender and ethnicity, were emailed to participating libraries. The replies to these queries were coded and analyzed to determine if discrimination occurred.

\section{E-service quality}

This study evaluates the quality of direct eservices that are provided by information professionals. Evaluation of direct e-services focuses on the technology-mediated interaction of the user with service providers directly and is different from the evaluation of indirect e-services that focuses, for example, on information systems and services portfolios, when the user does not interact directly with service providers. This study evaluates the equality of online mediated e-services interactions between service providers and users.

Online services experienced an extensive growth during the last decade, yet the quality of these online services is perceived to be inferior to traditional faceto-face services [43]. Over the past three decades researchers have made efforts to uncover the most important dimensions of perceived service quality [27]; lately these efforts have also focused on eservices quality [43]. Many of the dimensions for evaluation of service quality in the face-to-face environment are as influential in the virtual environment. For example, some of the dimensions include [27]: reliability (accuracy), responsiveness (promptness and timeliness), competence (knowledge and skills), access (approachability and accessibility), courtesy (politeness, respect, and friendliness), security (freedom of risk), understanding (individual attention), communication (explanations), credibility (trustworthiness by name and company name), and tangibles (material resources). Parasuraman, Zeithaml and Berry [28] attempt to expand the use of traditional service models to the internet using SERVQUAL, which includes five dimensions [24]: reliability (dependability and accuracy of service), responsiveness (prompt services), assurance (trust and confidence - based primarily on knowledge and courtesy of employees), empathy (caring and individualized attention to users), and tangibles (appearance of physical facilities and equipment) [28]. Parasuraman, Zeithaml, and Berry's [28] scale for measuring consumer perceptions of service quality are probably the most widely used [42]. These include:

"Tangible: Physical facilities, equipment, and appearance of personnel; Reliability: Ability to perform the promised service dependably and accurately; Responsiveness: Willingness to help customers and provide prompt service; Assurance: Knowledge and curtsey of employees and their ability to inspire trust and confidence; and Empathy: Caring, individualized attention the firm provides its customers." [28, p. 23]

Yang, Jun, and Peterson [43] identified 17 dimensions in the literature, 10 of which indicate customer service quality: responsiveness (prompt response), reliability (accurate and efficient response), competence, access (accessibility of service and contact information), personalization, courtesy, continuous improvement, communication, convenience, and control.

O'Neil, Wright, and Fitz [26] applied the SERVQUAL dimensions to examine the quality of online services in an Australian library and focused particularly on contact, responsiveness, reliability, and tangibles. Hernon and Calvert [19] developed a survey instrument, e-SERVQUAL for libraries, which focuses exclusively on examining library services online. They found that unlike the traditional five dimensions of SERVQUAL (tangible, reliability, responsiveness, assurance, and empathy) the most important dimensions to library users were (in order of importance) ease of use, collections, reliability, customization/ personalization, security/ privacy/ trust, support, ease of access, linkage, flexibility, and web site aesthetic.

These efforts to uncover the most important dimensions of service quality have focused on both direct and indirect e-services. Specific guidelines for the quality of direct e-services of information professionals and librarians have been published by professional associations. The International Federation 
of Library Association (IFLA) published the digital reference guidelines [20]. The American Library Association - Reference and User Services Association (RUSA) published the guidelines for implementing and maintaining virtual reference services [32], and the guidelines for behavioral performance of reference and information service providers [31]. Using these guidelines for direct services and Yang, Jun and Peterson's [43] dimensions of e-services, this study focuses on the following three quality dimensions:

\section{E-service - Responsiveness [43].}

Virtual reference - by acknowledgements of user email questions in a timely manner, providing patrons with responses as quickly as possible, and adherence to stated turnaround policy [21,31].

2. E-service - Reliability [43].

Virtual reference - by answering the query efficiently and correctly and providing a signature that contains the librarian's name or initials, title, and institution [21].

\section{E-service - Courtesy [43].}

Virtual reference - by friendliness, politeness, and professional courtesy [21, 31, 32].

This study focuses on the equality of e-service among user groups as evaluated on these three quality dimensions. Service equality is defined as the equal level of quality of services provided to all users, without discrimination on the ground of race or gender. Overall service quality is reduced when some users receive a lower level of service as measured by the three dimensions of quality evaluated in this study. Figure 1 provides a general overview of the model and relationships hypothesized in the study. Thus we examined the following three hypotheses:

H1. All user groups will receive a response in a timely manner.

H2. All user groups will receive the same level of efficient and reliable service.

H3. All user groups will receive equal quality of courtesy from e-services.

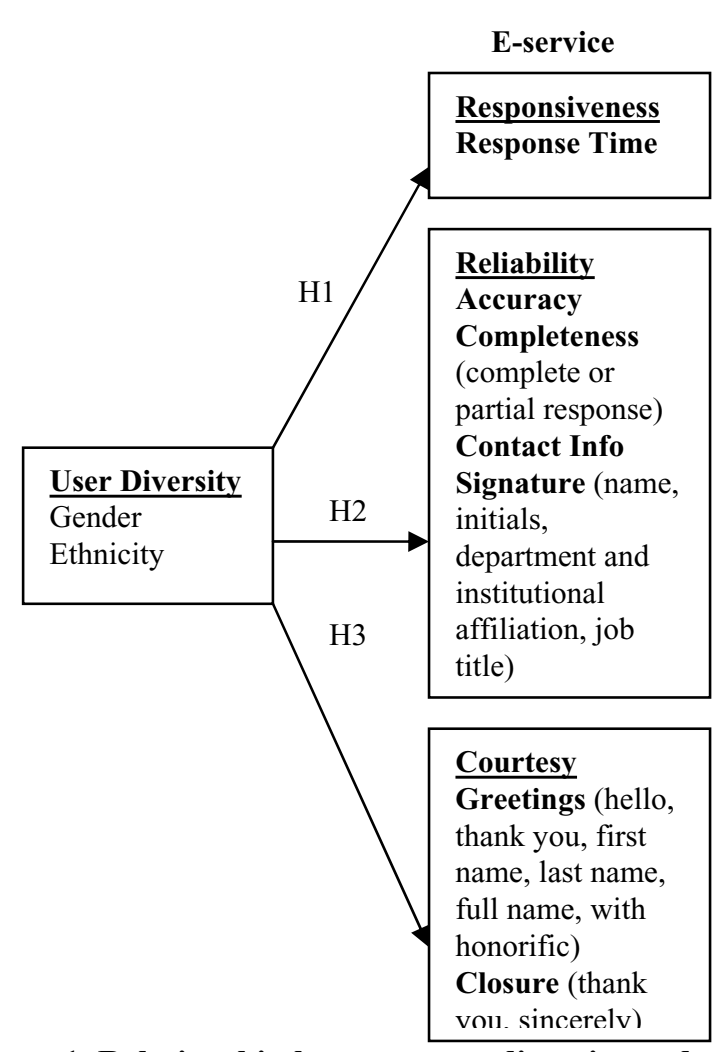

Figure 1. Relationship between user diversity and eservice quality

\section{Method}

An experiment using scenarios of information needs was conducted among public libraries in the United States that provide online reference services. The experimental feature of the study is that the requests have four different versions which differed only in the implicit ethnicity of the user, indicated by the users' names. The use of names perceived to be of a particular ethnicity is a common method to examine possible bias [3, 15]. Each version of the request represented one ethnic group and one gender: female African-American, male African-American, female Caucasian, and male Caucasian. The targeted eservice received a version of the same type of request but with a different user name, indicating a different ethnicity or gender. In this way, it was possible to determine whether service quality differed when salience of diversity is not an obvious factor and when all other factors are constant.

The names used to represent gender and ethnic groups are: Latoya Jones (female African-American), Tyrone Jackson (male African-American), Emily Baker (female Caucasian), and Todd Kelly (male Caucasian) [3]. We used names that have been 
rigorously verified to be names that most people would assume African-American ethnicity for certain names and Caucasian ethnicity for other names [3]. Bertrand and Mullainathan examined birth certificates from Massachusetts from 1974-1979 to create lists of names most frequently given to African-American and Caucasian infants [3]. They developed a list of 36 names, nine names for each of the four ethnic by gender groups: female Caucasians, female AfricanAmericans, male Caucasians, and male AfricanAmericans. These names were tested and confirmed in a pilot study before being used to examine possible bias in selecting and interviewing job applicants in two cities. Among the names used in their study were Latoya, Tyrone, Emily, and Todd; we chose these names as representative of their respective gender and ethnicities. Furthermore, since we portrayed our questioners as adults, the age range of names developed from Bertrand and Mullainathan's [3] study (born in 1974-1979) was appropriate. Since our use of these four names was based upon previous research, we were confident that the assumed gender and ethnicity would be identified by most recipients.

\subsection{Data collection}

During winter and spring 2006, 386 public libraries were recruited for participation using lib-web-cats [4], a publicly available directory of libraries throughout the world. ${ }^{1}$ Using this directory, we created a list of public libraries in the United States. We examined the first 20 states in the alphabetic list of states and for each state we identified public libraries that provided virtual reference services to their users. For each town, county, or city we selected the main library so our data will represent independent cases. Library consortia, statewide virtual reference services, and cooperative reference services, in which many institutions participate, were not included in the study. These were not included because some library consortia involve multi-type and academic libraries,

\footnotetext{
${ }^{1}$ Before conducting this study, we evaluated several directories of public libraries, and determined lib-web-cats and the online version of American Library Directory were the two sites likely to contain the most complete, accurate online directory of public libraries. We randomly chose a state, Connecticut, and then compared the number of functioning links to public libraries provided by each directory. Lib-web-cats [4] provided a list of 239 public libraries in Connecticut, of which $36.4 \%$ had functioning links for email or webform for reference services. American Library Directory (online) [1] provided 235 public libraries in Connecticut, of which $61.7 \%$ had functioning links for email or web-form for reference services. However, access to the online version of the American Library Directory was restricted to subscribed institutions and we utilized the free lib-web-cats directory.
}

and the current study was limited to only public libraries. Only libraries that provided a mailto link or a web form specifically for reference questions that users can complete were included in the sample list [39]. We expected to be able to identify many more relevant services from which to draw a representative sample, but were surprised to find that only $7.8 \%$ of the libraries on the lib-web-cat directory provided links to this service. ${ }^{2}$ We utilized the print version of American Library Directory [1] to verify names, titles, and email addresses of public library directors, then emailed recruitment letters and a link to an informed consent form to them. We recruited directors' consent to attempt unobtrusive study of reference service. Though we attempted unobtrusive study, the directors may have alerted their staff about the study, which may have affected the level of service provided. In addition, it is possible that library directors only agreed to the study if they were confident that their staffs did not discriminate. After recruitment, eighty-eight libraries agreed to take part in the study for a participation rate of $22.80 \%$. The participating libraries are located in all four of the regions defined by the U.S. Census Bureau. Approximately $23.9 \%$ of the libraries are in the South $44.3 \%$ are in the Midwest, $13.7 \%$ are in the Northeast and $18.2 \%$ are in the West.

Four reference queries were used which represented questions likely to be directed to public libraries. The requests were:

1. Town population: What was the population of [town in which library is located] in 2000?

2. Known item: Does your library have Romeo and Juliet? [or Does your library have Harry Potter and the Half-Blood Prince?]

3. Topical question: Can you help me find some resources about growing and taking care of rosebushes?

4. Ready reference: What is the average temperature in May in London?

Before the questions were sent, information about each library was collected so we could verify the accuracy of responses. We collected information about town populations using the Population Finder feature of the U.S. Census [40] and London

\footnotetext{
${ }^{2}$ This number may be lower than expected given previous reports in the literature [7], since we did not include statewide virtual reference services, which are often provided by a state library, a private company, a library school, or some other combination which did not fit the parameters of our study. Many libraries which did not provide online reference services themselves did provide links to these other services.
} 
temperature averages from the BBC Weather Service [5]. We used each library's online catalog to determine if they had Romeo and Juliet in their collection; for libraries whose online catalog was inaccessible, we asked them for a recent bestseller, Harry Potter and the Half-Blood Prince. We assumed that most libraries would have Romeo and Juliet and the latest Harry Potter book (which was borne out in our data collection).

In the spring of 2006 , email reference requests were sent to these 88 libraries; each e-service received one request per week during four consecutive weeks. The counterbalanced method was used to avoid variables confounding. The trick in counterbalancing is to make sure that each user name appears in each position an equal number of times. Each user sent the same number of messages, each library received only one request from each user, and each library received a specific type of request only once. Each week, a different question was received at the reference service of an institution from a different user.

Table 1. Data collection: The counterbalanced method

\begin{tabular}{|c|c|c|c|c|}
\hline & \multicolumn{4}{|c|}{ Questions sent to participating libraries } \\
\hline & Week 1 & Week 2 & Week 3 & Week 4 \\
\hline $\begin{array}{l}\text { First } \\
\text { set of } \\
\text { libraries }\end{array}$ & $\begin{array}{l}\text { Question } 1 \\
\text { - female } \\
\text { Caucasian }\end{array}$ & $\begin{array}{l}\text { Question } 2 \\
\text { - female } \\
\text { African- } \\
\text { American }\end{array}$ & $\begin{array}{l}\text { Question } 3 \\
\text { - male } \\
\text { Caucasian }\end{array}$ & $\begin{array}{l}\text { Question } 4 \\
\text { - male } \\
\text { African- } \\
\text { American }\end{array}$ \\
\hline $\begin{array}{l}\text { Second } \\
\text { set of } \\
\text { libraries }\end{array}$ & $\begin{array}{l}\text { Question } 2 \\
\text { - female } \\
\text { Caucasian }\end{array}$ & $\begin{array}{l}\text { Question } 3 \\
\text { - female } \\
\text { African- } \\
\text { American }\end{array}$ & $\begin{array}{l}\text { Question } 4 \\
\text { - male } \\
\text { Caucasian }\end{array}$ & $\begin{array}{l}\text { Question } 1 \\
\text { - male } \\
\text { African- } \\
\text { American }\end{array}$ \\
\hline $\begin{array}{l}\text { Third } \\
\text { set of } \\
\text { libraries }\end{array}$ & $\begin{array}{l}\text { Question } 3 \\
\text { - female } \\
\text { Caucasian }\end{array}$ & $\begin{array}{l}\text { Question } 4 \\
\text { - female } \\
\text { African- } \\
\text { American }\end{array}$ & $\begin{array}{l}\text { Question } 1 \\
\text { - male } \\
\text { Caucasian }\end{array}$ & $\begin{array}{l}\text { Question } 2 \\
\text { - male } \\
\text { African- } \\
\text { American }\end{array}$ \\
\hline $\begin{array}{l}\text { Fourth } \\
\text { set of } \\
\text { libraries }\end{array}$ & $\begin{array}{l}\text { Question } 4 \\
\text { - female } \\
\text { Caucasian }\end{array}$ & $\begin{array}{l}\text { Question 1 } \\
\text { female } \\
\text { African- } \\
\text { American }\end{array}$ & $\begin{array}{l}\text { Question } 2 \\
\text { - male } \\
\text { Caucasian }\end{array}$ & $\begin{array}{l}\text { Question } 3 \\
\text { - male } \\
\text { African- } \\
\text { American }\end{array}$ \\
\hline
\end{tabular}

A total of 352 email queries were sent. The day and time of requests (Monday afternoon) was kept constant so that any variability could be attributed to the gender or ethnic differences between the users. While sending messages at the same time may increase the possibility of a librarian becoming aware of the study and thus moderating response, the variation between types of messages and user names is likely to minimize this drawback. Table 1 describes the chronological order, user name, and type of question sent to a particular institution.

\subsection{Data analysis}

All 352 transactions were uploaded into Nvivo 2.0, a software that supports qualitative analysis. Using Nvivo facilitates content analysis and the search for frequencies and co-occurrences of codes and attributes. Further, Nvivo matrix capabilities assist in the identification of patterns among categories and also between categories and attributes.

Each transaction had been classified according to six attributes (each with multiple values) and a total of 49 codes. After all transactions were coded, intercoder reliability was calculated and resulted in $100 \%$ intercoder reliability, which is an extremely high level of reliability. Using SPSS 13.0, one-way ANOVA and cross tabulations were conducted to identify differences among user groups.

\section{Results}

The content analysis of the e-mail transactions revealed differences and similarities in the quality of service that virtual reference librarians provide to various users groups. Three hundred fifty two queries were sent to 88 libraries and 94 queries $(26.7 \%)$ received no response (Latoya - 23 queries; Emily - 23 queries; Tyrone - 23 queries; and Todd - 25 queries). Table 2 summarizes the frequencies of codes by users, showing how many times each user received a reply that contained one of these characteristics that indicate the two measures of quality - courtesy and reliability.

Table 2. Frequencies of codes by users

\begin{tabular}{llllll}
\hline Measure & Codes & $\begin{array}{l}\text { Emily } \\
\text { Baker }\end{array}$ & $\begin{array}{l}\text { Todd } \\
\text { Kelly }\end{array}$ & $\begin{array}{l}\text { Latoya } \\
\text { Jones }\end{array}$ & $\begin{array}{l}\text { Tyrone } \\
\text { Jackson }\end{array}$ \\
\hline Courtesy & $\begin{array}{l}\text { Greetings/Name/ } \\
\text { First Name }\end{array}$ & 25 & 21 & 21 & 20 \\
\hline $\begin{array}{l}\text { Greetings/Name/F } \\
\text { ull Name }\end{array}$ & 7 & 5 & 6 & 9 \\
\hline $\begin{array}{l}\text { Greetings/Name/ } \\
\text { With Honorific }\end{array}$ & 15 & 11 & 13 & 21 \\
\hline $\begin{array}{l}\text { Greetings/Name/ } \\
\text { Last Name }\end{array}$ & 6 & 8 & 9 & 15 \\
\hline $\begin{array}{l}\text { Greetings/Thank } \\
\text { you for using }\end{array}$ & 11 & 14 & 14 & 15 \\
\hline $\begin{array}{l}\text { Greetings/ } \\
\text { Greeting Hello }\end{array}$ & 16 & 18 & 20 & 14 \\
\hline $\begin{array}{l}\text { Closure/ Thank } \\
\text { you for using }\end{array}$ & 13 & 21 & 19 & 18 \\
\hline $\begin{array}{l}\text { Closure/ } \\
\text { Sincerely or } \\
\text { similar closing }\end{array}$ & 12 & 8 & 10 & 15 \\
\hline
\end{tabular}


Proceedings of the 40th Hawaii International Conference on System Sciences - 2007

\begin{tabular}{llllll}
\hline Measure & Codes & $\begin{array}{l}\text { Emily } \\
\text { Baker }\end{array}$ & $\begin{array}{l}\text { Todd } \\
\text { Kelly }\end{array}$ & $\begin{array}{l}\text { Latoya } \\
\text { Jones }\end{array}$ & $\begin{array}{l}\text { Tyrone } \\
\text { Jackson }\end{array}$ \\
\hline Reliability & $\begin{array}{l}\text { Answer/ } \\
\text { Complete }\end{array}$ & 29 & 22 & 25 & 31 \\
\cline { 2 - 5 } & $\begin{array}{l}\text { Answer/ } \\
\text { Accurate }\end{array}$ & 34 & 27 & 28 & 30 \\
\hline $\begin{array}{l}\text { Answer/ } \\
\text { Partial }\end{array}$ & 37 & 39 & 37 & 35 \\
\hline $\begin{array}{l}\text { Closure/ } \\
\text { Name of } \\
\text { Librarian }\end{array}$ & 42 & 44 & 43 & 43 \\
$\begin{array}{l}\text { Closure/ } \\
\text { Depart- } \\
\text { ment }\end{array}$ & 27 & 23 & 22 & 26 \\
\hline $\begin{array}{l}\text { Closure/ } \\
\text { Library } \\
\text { Name }\end{array}$ & 39 & 41 & 43 & 47 \\
$\begin{array}{l}\text { Closure/ } \\
\text { Contact } \\
\text { Info }\end{array}$ & 33 & 33 & 33 & 38 \\
\hline $\begin{array}{l}\text { Closure/ } \\
\text { Librarian } \\
\text { initials } \\
\text { Closure/ } \\
\text { Job Title }\end{array}$ & 5 & 3 & 29 & 4 \\
\hline
\end{tabular}

Table 3. Response time, in hours, by user

\begin{tabular}{lll}
\hline User $(\mathrm{N}=352)$ & $\mathrm{M}$ & $\mathrm{SD}$ \\
\hline Latoya Jones & 18.74 & 60.78 \\
\hline Emily Baker & 15.32 & 29.09 \\
\hline Tyrone Jackson & 12.12 & 17.84 \\
\hline Todd Kelly & 26.16 & 65.73 \\
\hline
\end{tabular}

H1 was supported; all users receive the same level of service in terms of responsiveness.

\subsection{Reliability}

Accuracy and completeness of responses were evaluated for each of the users to indicate level of eservice reliability. Table 2 provides frequencies for complete, partial and accurate responses for each question type. Complete responses included an answer to the question (such as the population of the town) as well as specific reference information. Partial responses included either the information sought, or reference information, but not both. Accurate answers were those that matched the data we located via

\subsection{Responsiveness} authoritative sources, such as the U.S. Census for population figures. A two-way contingency table analysis was conducted to evaluate whether response accuracy was different among the four users. As can be seen in Table 4, accuracy, complete, or partial responses were found to not be significantly related to the four users. A two-way contingency table analysis was conducted to evaluate whether response complete, partial, and accurate responses was different based on gender or ethnicity. Table 5 provides results of the cross tabulations by gender and ethnicity for reliability. Complete, partial and accurate answers were found not to be significantly related to ethnicity or gender (Table 5). All users were treated equally in terms of accuracy and completeness of the responses they received. No differences were found based on user ethnicity or gender.

Table 4. Cross tabulation results by user $\mathrm{p}=$ 714. A one-way analysis was conducted to evaluate the relationship between ethnicity and responsiveness and the ANOVA was found not to be significant $\mathrm{F}(1,297)=.894, \mathrm{p}=.345$.

\begin{tabular}{llll}
\hline $\begin{array}{l}\text { Code } \\
(\mathrm{N}=352, \mathrm{df}=3)\end{array}$ & $\begin{array}{l}\text { Pearson } \\
\chi^{2}\end{array}$ & $\begin{array}{l}\text { Cramer's } \\
\mathrm{V}\end{array}$ & $\begin{array}{l}\mathrm{p} \\
\text { value }\end{array}$ \\
\hline Greetings/ First Name & .901 & .051 & .825 \\
\hline Greetings/ Full Name & 1.404 & .063 & .705 \\
\hline $\begin{array}{l}\text { Greetings/ With } \\
\text { Honorific }\end{array}$ & 4.500 & .113 & .212 \\
\hline Greetings/ Last Name & 5.310 & .123 & .150 \\
\hline
\end{tabular}




\begin{tabular}{llll}
\hline $\begin{array}{l}\text { Code } \\
(\mathrm{N}=352, \mathrm{df}=3)\end{array}$ & $\begin{array}{l}\text { Pearson } \\
\chi^{2}\end{array}$ & $\begin{array}{l}\text { Cramer's } \\
\mathrm{V}\end{array}$ & $\begin{array}{l}\mathrm{p} \\
\text { value }\end{array}$ \\
\hline Greetings/Thank you & .787 & .047 & .852 \\
\hline $\begin{array}{l}\text { Greetings/ Greeting } \\
\text { Hello }\end{array}$ & 1.616 & .068 & .656 \\
\hline Answer/ Complete & 2.769 & .089 & .429 \\
\hline Answer/ Accurate & 1.46 & .064 & .692 \\
\hline Answer/ Partial & .373 & .033 & .946 \\
\hline Follow-Up & 2.311 & .081 & .510 \\
\hline $\begin{array}{l}\text { Closure/Name of } \\
\text { Librarian }\end{array}$ & .124 & .019 & .989 \\
\hline Closure/Department & .962 & .052 & .811 \\
\hline Closure/Library Name & 1.593 & .067 & .661 \\
\hline Closure/Contact Info & .896 & .050 & .826 \\
\hline Closure/Thank you & 2.452 & .083 & .484 \\
\hline Closure/Sincerely & 2.726 & .088 & .436 \\
\hline Closure/Job Title & .899 & .051 & .826 \\
\hline
\end{tabular}

Another indication of reliability of e-services is evaluated based on the provision of contact information and name of the service provider with departmental affiliation. The frequencies of inclusion of names, job title, department affiliation, library name, and contact information are described in Table 2 and the results of the cross tabulation is given in Table 4. As can be seen in Table 4 none of the cross tabulations for reliability were significant.

Table 5. Cross tabulation results by gender and ethnicity

\begin{tabular}{|c|c|c|c|c|}
\hline \multirow[t]{2}{*}{ Variable } & \multirow{2}{*}{$\begin{array}{l}\text { Gender } \\
\text { Pearson } \\
\chi^{2}\end{array}$} & \multicolumn{3}{|c|}{ Ethnicity } \\
\hline & & $\begin{array}{l}\text { Cramer's } \\
\underline{\mathrm{V}}\end{array}$ & $\begin{array}{l}\text { Pearson } \\
\chi^{2}\end{array}$ & $\begin{array}{l}\text { Cramer's } \\
\underline{\mathrm{V}}\end{array}$ \\
\hline \multicolumn{5}{|l|}{ Courtesy } \\
\hline $\begin{array}{l}\text { Greetings / } \\
\text { First Name }\end{array}$ & .431 & .036 & .586 & .072 \\
\hline $\begin{array}{l}\text { Greetings / } \\
\text { Full Name }\end{array}$ & .040 & .011 & .363 & .033 \\
\hline $\begin{array}{l}\text { Greetings / } \\
\text { With } \\
\text { Honorific }\end{array}$ & .325 & .031 & 1.302 & .063 \\
\hline $\begin{array}{l}\text { Greetings / } \\
\text { Last Name }\end{array}$ & 1.9 & .076 & 2.97 & .095 \\
\hline $\begin{array}{l}\text { Greetings / } \\
\text { Thank you }\end{array}$ & .354 & .033 & .354 & .033 \\
\hline $\begin{array}{l}\text { Greetings / } \\
\text { Hello }\end{array}$ & .296 & .030 & .000 & .000 \\
\hline
\end{tabular}

\begin{tabular}{|c|c|c|c|c|}
\hline \multirow[t]{2}{*}{ Variable } & \multirow{2}{*}{$\begin{array}{l}\text { Gender } \\
\text { Pearson } \\
\chi^{2} \\
\end{array}$} & \multicolumn{3}{|l|}{ Ethnicity } \\
\hline & & $\begin{array}{l}\text { Cramer's } \\
\underline{\mathrm{V}}\end{array}$ & $\begin{array}{l}\text { Pearson } \\
\chi^{2}\end{array}$ & $\begin{array}{l}\text { Cramer's } \\
\underline{\mathrm{V}}\end{array}$ \\
\hline $\begin{array}{l}\text { Closure / } \\
\text { Thank You }\end{array}$ & .878 & .054 & .161 & .022 \\
\hline $\begin{array}{l}\text { Closure / } \\
\text { Sincerely }\end{array}$ & .579 & .042 & .643 & .044 \\
\hline \multicolumn{5}{|l|}{ Reliability } \\
\hline Complete & .014 & .006 & .345 & .032 \\
\hline Partial & .000 & .000 & .110 & .018 \\
\hline Accurate & .250 & .027 & .118 & .019 \\
\hline $\begin{array}{l}\text { Closure / } \\
\text { Name of } \\
\text { Librarian }\end{array}$ & .048 & .012 & .000 & .000 \\
\hline $\begin{array}{l}\text { Closure / } \\
\text { Department }\end{array}$ & .000 & .000 & .058 & .013 \\
\hline $\begin{array}{l}\text { Closure / } \\
\text { Library } \\
\text { Name }\end{array}$ & .434 & .036 & 1.206 & .060 \\
\hline $\begin{array}{l}\text { Closure / } \\
\text { Contact Info }\end{array}$ & .713 & .047 & .713 & .047 \\
\hline $\begin{array}{l}\text { Closure / } \\
\text { Librarian } \\
\text { Initials }\end{array}$ & .000 & .000 & .298 & .030 \\
\hline $\begin{array}{l}\text { Closure / Job } \\
\text { Title }\end{array}$ & .218 & .026 & .489 & .038 \\
\hline $\begin{array}{l}\mathrm{N}=324 \\
* \mathrm{p}<.05 \\
* * \mathrm{p}<.01\end{array}$ & & & & \\
\hline
\end{tabular}

H2 was supported; all users receive the same level of service in terms of reliability.

\subsection{Courtesy}

The ways the user is addressed by librarians is another indication of the quality of service. The use of honorifics and greetings indicate a higher level of politeness and the use of first name indicates a higher level of friendliness (in the United States). Similarly, including "thank you for using the service" in the message is another indication of quality. The frequencies of greetings, honorifics, first name, full name, last name and thank you (greetings and closure) in the responses for each of the four user are described in Table 2. The results of the cross tabulation analysis for each of these quality indications were found to be not significant (Table 4). Table 5 provides results of the cross tabulations by gender and race for courtesy. All greetings measures and closure measures were found not to be significantly related to users (Table 5). All users were treated equally in terms of courtesy. No differences were found based on user ethnicity or gender. 
H3 was supported; all users received the same level of service in terms of courtesy.

\section{Discussion}

Title II of the 1964 Civil Rights Act states that "all persons shall be entitled to the full and equal enjoyment of the goods, services, facilities, privileges, advantages, and accommodations of any place of public accommodation... without discrimination or segregation on the ground of race, color, religion, or national origin." A core norm of the library profession is the provision of "high level of service to all library users through... accurate, unbiased, and courteous responses to all requests" [2]. This language is echoed in the Core Values statement of IFLA [21]. When Dole and Hurych [12] asked library science students at one university to rank the three most important values of the profession, $89 \%$ of students included "service to clientele" and $32 \%$ included "equitable access" in this top tier. Free and equal access is a core ethical principle that is found in all library ethical values typologies [e.g., 16, 22, 18, 25, 33, 34, 37]. Shachaf [34] found that equal access was one of the few core values of the library profession that was shared across 23 countries around the globe.

Despite these core values and the professional standards, service providers, including librarians, at times might provide unequal service to the public. Discrimination on ethnic, race, gender, age, or religious grounds has been observed and reported extensively in the literature. For example, Cesare [6] reviewed studies that focused attention on discriminatory behaviors in employment interviews. Riesch and Kleiner [30], for example, reported about recent cases of service discrimination on the ground of race and disabilities in restaurants. These are not unique to restaurants but have been largely documented in public accommodations [14]. Studies on library discrimination are scarce and limited to studies of gender and race bias in employee recruitment and promotion [9]. Service discrimination is an understudied research domain in librarianship. It is possible that librarians do not discriminate against users on the grounds of race or gender when providing traditional library services, but it is equally possible that they do. Online discriminatory behaviors of academic librarians in asynchronous mediated communication of virtual reference services were found, even when blatant differences were not evident [35]. Unlike these findings our study found that differences in quality of e-services in public libraries among user groups exist but these are not statistically significant. Due to the sampling procedure we used, these results may not be generalizable to all U.S. public libraries. It is possible that these findings are confined to public libraries and may not be generalized to other type of libraries. It is also possible that these findings can be generalized to library services only (in the United States) and that they reflect the adherence of librarians to their professional ethics and core values [2]. But, at the same time it is possible that these findings accurately describe the potential of e-services for equality.

The potential of the virtual environment for equalization was documented in the context of group decision making [e.g., 10, 11, 38]. It was likewise suggested that email enabled multinational computermediated teams overcome challenges associated with intercultural miscommunication [36]. Similarly, our study provides support for claims in favor of the potential of online services in overcoming cultural diversity gaps. Yet, comparative analysis of virtual and traditional service bias should be conducted in the future to shed light on the extent of reduction in online subjective bias compared to traditional setting. Similarly it is possible that unequal services exist on the other grounds, such as country of origin or religion. Future studies may focus on equality of service in global context, in particular as off-shoring customer services proliferate.

Evaluation of e-services quality should focus attention on the quality of services also in terms of equality. Since all users are entitled to the best level of service, successful e-services are those that do not discriminate users on race or gender grounds. Quality indictors should be applied across user groups to assure E-quality. Similarly, non-discriminatory behavior should be included in performance evaluation of individuals who provide e-services to the public.

\section{Conclusion}

Does E-quality equal equality? This study can tentatively answer "yes." We found no significant differences based on race or gender in the quality of eservices that libraries provide to the public on all three indicators of e-service quality. The quality of service to all user groups was equal in terms of courtesy, reliability, and responsiveness. We conclude that the virtual environment has the potential to enable better and equal services to all users without bias on the ground of age, disability, race, gender, ethnicity, and country of origin.

Future studies should examine the extent of discrimination in both settings (virtual and face-to- 
face), or when using different types of technologies to provide services (phone, video-conference, email, chat, and face-to-face). Other future research directions may involve examination of real reference transactions or transactions from other type of e-services, which are not provided by librarians. In addition, future research could expand this study to include other races or ethnic groups. Other service-oriented professions, many of which, like librarians, are increasingly utilizing the internet to provide services, can also be evaluated in terms of equality of service. It is possible that librarians' training in core values such as equality and service has contributed to their ability to equitably serve diverse users online. If that is so, other service professionals may improve the equality of their service by developing and inculcating such values themselves.

\section{References}

[1] American Library Association. (2005). American Library Directory Online. Chicago: American Library Association.

[2] American Library Association. (1995). Code of Ethics of the American Library Association. Retrieved May 31, 2006 from

http://www.ala.org/ala/oif/statementspols/codeofethics/c odeethics.htm

[3] Bertrand, M., \& Mullainathan, S. (2004). Are Emily and Greg more employable than Lakisha and Jamal? A field experiment on labor market discrimination. The American Economic Review, 94(4), 991-1013.

[4] Breeding, M. (2006). Lib-web-cat: A directory of libraries throughout the world. Retrieved June 5, 2006 from http://www.librarytechnology.org/libwebcats/

[5] British Broadcasting Corporation. (2006). BBC Weather. Retrieved June 5, 2006, from http://www.bbc.co.uk/weather/world/city_guides/results .shtml?tt=TT003790

[6] Cesare, S.J. (1996). Subjective judgment and the selection interview: A methodological review. Public Personnel Management, 25(3), 291-305.

[7] Coffman, S. (2003). Going live: Starting and running a virtual reference service. American Library Association: Chicago.

[8] Crosby, F., Bromley, S., \& Saxe, L. (1980). Recent unobtrusive studies of Black and White discrimination and prejudice: A literature review. Psychological Bulletin, 87, 546-563.

[9] Curry, D.A. (1994). Your worries ain't like mine: African American librarians and the pervasiveness of racism, prejudice and discrimination in academe. The Reference Librarian, 45/46, 299-311.

[10] Daily, B.F., \& Steiner, R.L. (1998). The influence of group decision support systems on contribution and commitment levels in multicultural and culturally homogeneous decision-making groups. Computers in Human Behavior, 14(1), 147-162.
[11] Daily, B., Whatley, A., Ash, S. R., \& Steiner, R.L. (1996). The effects of a group decision support system on culturally diverse and culturally homogeneous group decision making. Information \& Management, 30, 281-289.

[12] Dole, W.V., \& Hurych, J.M. (2001). Values for librarians in the information age. Journal of Information Ethics, 10(2), 38-50.

[13] Douglas, K. M., \& McGarty, C. (2001). Identifiability and self-presentation: Computer-mediated, communication and intergroup interaction. British Journal of Social Psychology, 40, 3, 399-416.

[14] Feagin, J. (1991). The continuing significance of race: Antiblack discrimination in public places. American Sociological Review, 1, 101-116.

[15] Figlio, D. N. (2005). Names, expectations and the Black-White test score gap. NBER Working Paper No. W11195. retrieved June 7, 2006 from: $\mathrm{http}: / / \mathrm{ssrn} . \mathrm{com} / \mathrm{abstract}=684721$

[16] Froehlich, T. (1997). Survey and analysis of the major ethical and legal issues facing library and information services. Munich, Germany: K.G. Saur.

[17] Glaser, J., \& Kahn, K. B. (2005). Prejudice and discrimination and the internet. in Y. AmichaiHamburger (Ed.). The social psychology of the internet. Oxford, UK: Oxford University Press.

[18] Gorman, M (2000). Our enduring values: Librarianship in the 21st century. Chicago, IL: American Library Association.

[19] Hernon, P., \& Calvert, P. (2005). E-service quality in libraries: Exploring its feature and dimensions. Library \& Information Science Research, 27, 377-404.

[20] International Federation of Library Associations and Institutions. (2005a). IFLA digital reference guidelines. Retrieved January 5, 2006 from: http://www.ifla.org/VII/s36/pubs/drg03.htm.

[21] International Federation of Library Associations and Institutions. (2005b). More about IFLA. Retrieved May 10, 2006 from: http://www.ifla.org/III/intro00.htm

[22] Koehler, W.C., \& Pemberton, J.M. (2000). A search for core values: Towards a model code of ethics for information professionals. Journal of Information Ethics 9, 27-54.

[23] LaPiere, R. T. (1934). Attitudes vs. actions. Social Forces, 13, 230-237.

[24] Madu, C.N., \& Madu, A.A. (2002). Dimensions of Equality. International Journal of Quality and Reliability Management, 19(3), 246-258.

[25] Mason, R.O. (1986). Four ethical issues of the information age. Management Information Systems Quarterly, 10, 5-12.

[26] O’Neill, M., Wright, C., \& Fitz, F. (2001). Quality evaluation in on-line service environments: An application of the importance-performance measurement technique. Managing Service Quality, $11(6), 402-417$.

[27] Parasuraman, A. (1985). A conceptual model of service quality and its implications for future research. Journal of Marketing, 49, 41-50. 
[28] Parasuraman, A., Zeithaml, V. A., \& Berry, L. L. (1988). SERVQUAL: A multiple item scale for measuring consumer perceptions of service quality. Journal of Retailing, 64(1), 12-40.

[29] Pew Internet \& American Life Project. (2005). Latest trends: Who is online. Retrieved January 28, 2006 from: http://www.pewinternet.org/trends/User_Demo_12.05.0 5.htm.

[30] Riesch, C., \& Kleiner, B. H. (2005). Discrimination towards customers in the restaurant industry. Equal Opportunities International, 24(7/8), 29-37.

[31] Reference and User Services Association. (2004a). Guidelines for behavioral performance of reference and information service providers. Retrieved January 5 , 2006 from:

http://www.ala.org/ala/rusa/rusaprotools/referenceguide/ guidelinesbehavioral.htm

[32] Reference and User Services Association. (2004b). Guidelines for implementing and maintaining virtual reference services. Retrieved September 20, 2005 from: http://www.ala.org/ala/rusa/rusaprotools/referenceguide/ virtrefguidelines.htm.

[33] Rubin, R. \& Froehlich, T. (1996). Ethical aspects of library and information science. In: Encyclopedia of library and information science, (Vol. 58, Suppl. 21, pp. 33-52). New York: Mercel Dekker.

[34] Shachaf, P. (2005a). A global perspective on library association codes of ethics. Library \& Information Science Research, 27(4), 513-533.

[35] Shachaf, P. (2005b). Are virtual reference services color blind? [electronic version]. Proceedings of the 7th Annual Virtual Reference Desk. San-Francisco, CA, November 14-15, 2005. Retrieved June 5, 2006 from: http://data.webjunction.org/wj/documents/12437.pdf

[36] Shachaf, P. (2005c). Bridging cultural diversity through email. Journal of Global Information Technology Management, 8(2), 46-60.

[37] Smith, M. (1997). Information ethics. Annual Review of Information Science \& Technology 32, 339-366.

[38] Sproull, L., \& Keisler, S. (1986). Reducing social context cues: Electronic mail in organizational communication. Management Science, 32, 1492-1513.

[39] Stacy- Bates, K. (2003). E-mail reference responses from Academic ARL libraries: An unobtrusive study. Reference and User Services Quarterly, 43(1), 59-70.

[40] US Census Bureau. (2006). Population Finder. Retrieved June 5, 2006, from: http://www.census.gov/

[41] US Census Bureau. (2004). United States population and housing narrative profile, 2004 data set: American community survey. Retrieved January 28, 2006 from: http://factfinder.census.gov/servlet/NPTable?_bm=y\&geo_id $=01000$ US\&qr_name=ACS_2004_EST_G00_NP01\&-ds_name = \& redoLog=false.

[42] Voss, C.A. (2003). Rethinking paradigms of service: Service in a virtual environment, International Journal of Operations \& Production Management, 23(1), 88104.
[43] Yang, Z., Jun, M., \& Peterson, R.T. (2004). Measuring costumer perceived online service quality: Scale development and managerial implications. International Journal of Operations \& Production Management, 24(11/12), 1149-1174. 